\title{
Effect of cold and frozen temperatures on artisanal goat cheese containing probiotic lactic acid bacteria isolates (Lactobacillus plantarum TW14 and Lactobacillus rhamnosus TW2)
}

\author{
Triana Setyawardani, Juni Sumarmono and Kusuma Widayaka \\ Department of Animal Production, Faculty of Animal Science, Jenderal Soedirman University, Purwokerto, Indonesia. \\ Corresponding author: Triana Setyawardani, e-mail: trianaunsoed@gmail.com \\ Co-authors: JS: masjuni@gmail.com, KW: kwidayaka@gmail.com \\ Received: 13-09-2018, Accepted: 08-02-2019, Published online: 16-03-2019
}

doi: 10.14202/vetworld.2019.409-417 How to cite this article: Setyawardani T, Sumarmono J, Widayaka K (2019) Effect of cold and frozen temperatures on artisanal goat cheese containing probiotic lactic acid bacteria isolates (Lactobacillus plantarum TW14 and Lactobacillus rhamnosus TW2), Veterinary World, 12(3): 409-417.

\begin{abstract}
Aim: The research was conducted to determine the effect of temperature and storage duration on the physicochemical, lipolytic, microbiological, and proteolytic characteristics of goat cheese made using Lactobacillus plantarum TW14 and Lactobacillus rhamnosus TW2 bacteria.

Materials and Methods: The cheese was stored at $4{ }^{\circ} \mathrm{C}$ and $-20^{\circ} \mathrm{C}$ for $0,15,30,45$, and 60 days. Observations were made on its physicochemical, lipolysis, and microbiological characteristics. The proteolysis pattern was measured with sodium dodecyl sulfate-polyacrylamide gel electrophoresis.

Results: The protein, fat, ash and total solids levels of cold-stored cheese were higher than the frozen-stored one. The frozen-stored cheese's free fatty acids (FFA) and acid degree value (ADV) levels are lower than those of the cold-stored cheese as indicated by the partial lipolysis event. The total yeast in the frozen-stored cheese is lower than that in the frozenstored cheese. Finally, the electrophoresis profile indicates that proteolysis of the frozen-stored cheese is formed since there have been detected $\alpha_{\mathrm{s} 1}$-casein, $\alpha_{\mathrm{s} 2}$-casein, $\beta$-casein, and $\kappa$-casein in the casein breakdown during the 60 -day storage.
\end{abstract}

Conclusion: The physicochemical characteristics of cold-stored cheese are better than the cheese stored at frozen temperature. However, frozen-stored cheese produces lower FFA and ADV than cold-stored cheese and lipolysis occurs only partially.

Keywords: cheese, lipolysis, physicochemical, proteolysis.

\section{Introduction}

Goat cheese has been commonly produced in many countries. Many use probiotic lactic acid bacteria (LAB) of Lactobacillus spp. and Bifidobacterium spp., which have been proven capable of improving health. Previously, we isolated and identified two indigenous LAB (Lactobacillus plantarum TW14 and Lactobacillus rhamnosus TW2) from the milk of local Indonesia goat breeds [1], which were proven resistant to low $\mathrm{pH}$ and bile salt $0.3 \%$ and capable of colonizing in the intestinal epithelium, possessing antimicrobial property [2]. Both types of LAB are used as a starter to produce cheese which is expected to generate specific characteristics in goat cheese different from any existing goat cheese. L. plantarum TW14 and L. rhamnosus TW2 are used in this work to manufacture cheese from goat milk. The use of mixed probiotic bacteria improves the viability of probiotic in cheese when compared to a single strain, [3], which were similar to the observation on whey cheese [4].

Copyright: Setyawardani, et al. Open Access. This article is distributed under the terms of the Creative Commons Attribution 4.0 International License (http://creativecommons.org/licenses/ by/4.0/), which permits unrestricted use, distribution, and reproduction in any medium, provided you give appropriate credit to the original author(s) and the source, provide a link to the Creative Commons license, and indicate if changes were made. The Creative Commons Public Domain Dedication waiver (http:// creativecommons.org/publicdomain/zero/1.0/) applies to the data made available in this article, unless otherwise stated.
Cheese is potential for delivering probiotic $\mathrm{LAB}$ to the gut; however, storage temperature and duration during distribution and display might affect the survivability of the probiotics and cheese characteristics. Previous study [5] was only limited on storage under room and cold temperature of the cheese. This study was performed to endeavor the effect of frozen storage condition. That storage condition can maintain food quality for a longer time. The advantage is that the food could be distributed in a longer distance than other methods. In addition, the room temperature storage accelerates the ripening of ripened cheese type [5]. Under cold and frozen storage, cheese texture becomes finer, and the consistency solidifies, the flavor is formed more perfect, and the LAB metabolite is produced. These changes occur due to the proteolysis process and interaction of LAB in the cheese matrix [6-8]. The LAB viability during storage is also influenced by its resistance to the storage temperature. In frozen temperature, ice crystals are formed and will disrupt the LAB growth as well as decrease the viability. The previous study proved that the stored cheese on cold temperature also changed its metabolite and LAB viability [3]. The viability could be maintained up to $9.69 \pm 0.12 \log$ colony-forming unit $(\mathrm{CFU}) / \mathrm{g}$. The storage duration contributed to the amount of volatile compounds produced and the biochemical changes [5]. This biochemical process and microbial 
interaction during the storage will be beneficial since it will improve the flavor and texture of cheese; both are important in improving the probiotic cheese quality. The existence of probiotic bacteria is expected to improve the functional property of the cheese as well since the consumption of probiotic in an adequate amount will improve the body's physiological function.

The novelty of this study is that we used indigenous LAB isolated from the milk of local Indonesia dairy goats. The isolates (L. plantarum TW14 and L. rhamnosus TW2) were particularly promising as probiotics. Incorporation of these LABs into cheese would create an opportunity to produce a kind of probiotic cheese, which has functional properties. Therefore, this study aimed to investigate the effects of storage condition (cold and frozen) as well as storage duration on the physicochemical, lipolytic, microbiological, and proteolytic characteristics of goat cheese manufactured using L. plantarum TW14 and L. rhamnosus TW2 bacteria.

\section{Materials and Methods}

\section{Ethical approval}

Ethical approval was not needed for this study.

\section{Materials}

The probiotic culture of L. rhamnosus TW2 and L. plantarum TW14 was isolated previously [1]. Commercial animal rennet, microbiology media of de Man Rogosa and Sharpe Broth (MRSB) (Difco Laboratories Detroit, MN, USA), phosphate buffer saline (Sigma Aldrich, Missouri, USA), and chemicals were collected for laboratory analysis. Tools used in this experiment consisted of cheese manufacturing tools, an incubator, proximate analysis apparatus, and sodium dodecyl sulfate-polyacrylamide gel electrophoresis.

\section{Methods}

\section{Culture starter making}

The L. plantarum TW 14 and L. rhamnosus TW2 isolates were isolated from goat milk [1]. Each of these isolates was taken one ose, and then, it was grown in MRSB for $24 \mathrm{~h}$ at $37^{\circ} \mathrm{C}$ until it was turbid, which means that isolate concentration is about $10^{8} \mathrm{CFU} / \mathrm{mL}$ and ready to use as a starter.

\section{Cheese production process}

Fresh goat milk was obtained from a farmer in Ajibarang ( $2 \mathrm{~h}$ from the laboratory), then immediately pasteurized at $62^{\circ} \mathrm{C}$ for $30 \mathrm{~min}$, and then cooled down to $40^{\circ} \mathrm{C}$. The L. plantarum TW14 and L. rhamnosus TW2 isolates $\left(10^{8} \mathrm{CFU} / \mathrm{mL}\right.$ each) were added at $5 \%$ concentration of total milk $(\mathrm{v} / \mathrm{v})$ with $1: 1$ ratio for each isolate, then incubated it for approximately $4 \mathrm{~h}$ until its $\mathrm{pH}$ decreases to about 6.1 , then added the rennet at $0.06 \mu \mathrm{l} / \mathrm{L}$ milk, and let it settle until a pudding-like lump is formed. The lump was cut and heat at $40^{\circ} \mathrm{C}$ for $10 \mathrm{~min}$ and then separates the solids and fluids by filtering. The solids were pressed and stored at cold $\left(4^{\circ} \mathrm{C}\right)$ and frozen $\left(-20^{\circ} \mathrm{C}\right)$ for 60 days.

\section{Chemical composition}

The protein (Kjeldahl's method), fat (Babcock's method), moisture for dry matter, and ash were measured according to the standards of AOAC [6].

\section{Salt level}

The salt level of the cheese was determined using titration with $\mathrm{AgNO}_{3}$ [7].

\section{pH}

The $\mathrm{pH}$ was measured using a $\mathrm{pH}$ meter (Hanna Instrument 8519, Incofar, Modena, Italy), and the cheese amounting to $10 \mathrm{~g}$ was blended into $10 \mathrm{~mL}$ distilled water [8].

\section{Acid degree value (ADV)}

ADV was determined as follows [9], approximately $10 \mathrm{~g}$ of sample was ground, homogenized, and placed into a Babcock cheese bottle for fat extraction. $1 \mathrm{~mL}$ of the final extracted fat was titrated against the standard alcoholic 0.02N KOH (Merck, Darmstadt, Germany) solution. Calculation of ADV was performed using the following formulation:

$$
\mathrm{ADV}=\frac{\mathrm{mLKOH} \text { in sample }-\mathrm{mL} \mathrm{KOH} \mathrm{blank} \times \mathrm{N} \times 100}{\text { Weight of fat }(\mathrm{g})}
$$

where $\mathrm{N}=$ normality of $\mathrm{KOH}$ solution in methanol (Merck, Darmstadt, Germany)

\section{Free fatty acids (FFA)}

The method to quantify FFA was based on titration of $\mathrm{NaOH}$ (Merck, Darmstadt, Germany) that was described by Park [10]. The cheese was ground, and then, $10 \mathrm{~g}$ of them were added with $50 \mathrm{~mL}$ of $96 \%$ alcohol (Merck, Darmstadt, Germany) and $2 \mathrm{~mL}$ of phenolphthalein indicator (Merck, Darmstadt, Germany). The mixture was then titrated with $0.1 \mathrm{~N} \mathrm{NaOH}$ until pink color appeared and made sure that it was stable for 30 s. The calculation was carried to the formula below:

$\mathrm{FFA}=\mathrm{mL} \mathrm{NaOH}$ titrated for a sample $-\mathrm{mL} \mathrm{NaOH}$ titrated for the blank sample $\times \mathrm{N} \times 100$ Weight of sample $(\mathrm{g})$

where $\mathrm{N}=$ normality of $\mathrm{NaOH}$ solution

\section{Quantification of cheese LAB and yeast}

About $20 \mathrm{~g}$ of sample was mixed with $180 \mathrm{~mL}$ of $2 \%$ sterile sodium citrate solution (Sigma Aldrich, Missouri, USA) (w/v) and homogenized in Stomacher (Fisher Scientific, Hampton, NH) at 12,000 rpm for $3 \mathrm{~min} .1 \mathrm{~mL}$ of the homogenized solution was taken and serially diluted up to $1: 10^{8}$. The sample of the three highest dilutions specifically $10^{6}, 10^{7}$, and $10^{8} \mathrm{CFU} / \mathrm{mL}$ was taken $1 \mathrm{~mL}$ each aseptically and poured into a sterile Petri dish and MRSA (Difco Laboratories Detroit, MN, USA). Media was added and then incubated at $37^{\circ} \mathrm{C}$ for $48 \mathrm{~h}$ to calculate the amount of LAB by total plate count method, and the total yeast is grown in PDA (Difco Laboratories Detroit, MN, USA) followed by same quantification method [8]. 


\section{Proteolysis profile}

Proteolysis profile was performed using gel electrophoresis as described by Laemmli [11] with some modifications. $1 \mathrm{~g}$ of cheese was defatted by extracting with diethyl ether, dissolved in solution containing $1 \mathrm{~mL}$ of EDTA (Sigma Aldrich, Missouri, USA) (1\%), $1 \mathrm{~mL}$ of sodium deoxycholic (Merck, Darmstadt, Germany) (1\%), and $5 \mathrm{~mL}$ of urea (Sigma Aldrich, Missouri, USA) $(50 \% \mathrm{w} / \mathrm{v})$. The $\mathrm{pH}$ of the solution was set at 7.0 and ripened at $4{ }^{\circ} \mathrm{C}$ for $24 \mathrm{~h}$. The sample was then diluted with sample buffer (Sigma Aldrich, Missouri, USA) $1: 4 \mathrm{v} / \mathrm{v}$ and denaturated in $95^{\circ} \mathrm{C}$ for 5 min. The samples were loaded to $12 \%$ gel (acrylamide: bis-acrylamide; 29:1) (Merck, Darmstadt, Germany) along with Chromatein Protein Ladder (Vivantis Technologies, Selangor, Malaysia); then, the electrophoresis was performed in $150 \mathrm{~V}$ for $30 \mathrm{~min}$. These processes were followed by coomassie staining (Sigma Aldrich, Missouri, USA), and documentation.

\section{Statistical analysis}

The data were collected and presented as means \pm standard deviation. The procedure of general linear model was employed, followed by Duncan's multiple range test for mean comparison.

\section{Results and Discussion}

The milk used as the raw material for cheese production has a total number of bacteria $3.97 \log \mathrm{CFU} / \mathrm{mL}$, and on pasteurization, it reduces to $2.81 \log \mathrm{CFU} / \mathrm{mL}$. The amount of probiotic LAB used collectively, i.e., L. plantarum TW14 and L. rhamnosus TW2 in the culture starter is shown in Figure-1. In the cheese curd, LAB amounting 8.77 is obtained before the cheese is given different temperature and storage duration treatments. The fresh milk used has $\mathrm{pH} 6.8$ and the starter has $\mathrm{pH} 4.2$ during the incubation process. The milk $\mathrm{pH}$ decreases to 4.5 after the starter is added. During the cheese production process, the whey and curd are separated with the whey $\mathrm{pH} 4.4$ and the curd $\mathrm{pH} 5.2$ (Figure-2).

\section{Cheese chemical composition}

The goat cheese was produced using L. plantarum TW14 and L. rhamnosus TW2 probiotic isolates as its starter. These isolates were isolated from the milk of goat of Ettawa crossbreed, and its chemical composition is shown in Table-1.

Any cheese stored in cold temperature will have protein contents, and the cheeses made using L. plantarum TW14 and L. rhamnosus TW2 starter culture have protein contents from $17.57 \%$ to $21.32 \%$. The storage duration of cheese at different temperatures has a significant influence $(\mathrm{p}<0.05)$, and the different storage durations have a significant influence $(\mathrm{p}<0.05)$ on the cheese's protein content.

The fat contents as found by this research range from $20.08 \pm 2.12 \%$ to $29.36 \pm 1.69 \%$, with the lowest fat content found in the cheese treated with 15-day frozen storage and the highest averaged in the cheese treated

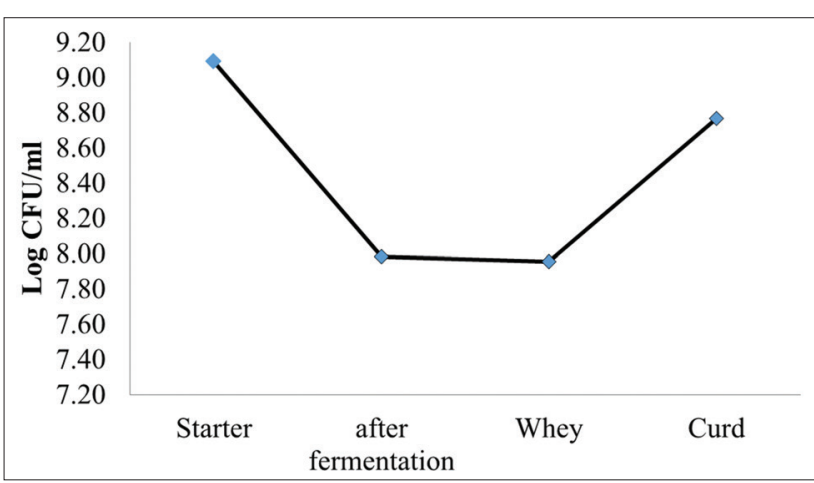

Figure-1: Total count of lactic acid bacteria in each manufacturing step.

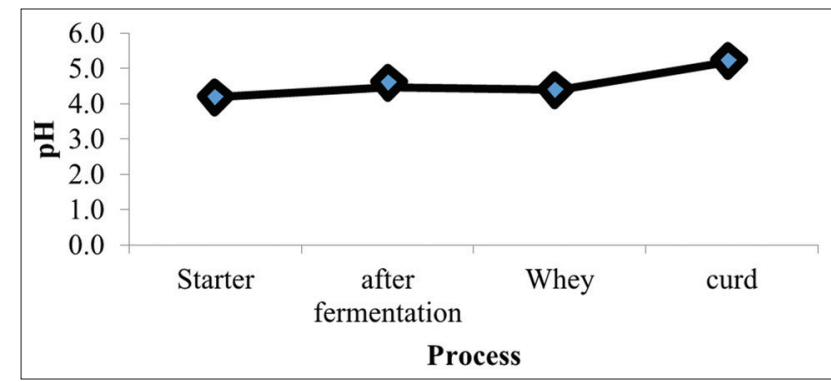

Figure-2: $\mathrm{pH}$ values in each manufacturing step.

with no storage at cold storage. The cheese storage temperature, the storage duration up to 60 days, and the interaction between temperature and storage duration have an insignificant influence $(p>0.05)$ on the cheese's fat content. The cheese with no storage duration produces the highest fat content, and it decreases during the storage.

The ash content as found in the research ranges between $1.75 . \pm 0.08 \%$ and $6.10 \pm .0 .71 \%$, with the highest ash content value found in the refrigerator temperature treatment for 45 -day storage, i.e., at $6.10 \pm .0 .71 \%$. The lowest ash content is found in the cheese before its storage in freezer storage, i.e., $1.75 . \pm 0.08 \%$. The cheese storage temperature, the storage duration up to 60 days, and their interaction have a significant influence $(p<0.05)$ on the cheese ash content. The produced ash content during the 30-day storage has the highest at $3.09 \%$. The obtained value is lower than that found by Laemmli [11], i.e., $4.37 \%$.

The water content of the cheese stored in freezer is higher than that stored at refrigerator temperature, with the highest found in the cheese stored for 45 days in both cheeses, frozen and cold storage, i.e., respectively, at 57.33 and 48.28 , and the same applies to the total solid cheese as well. Temperature and storage duration influence the cheese salt content $(p<0.05)$, where the salt content is higher in the cheese stored in the refrigerator than that of the cheese stored in the freezer. The longer the duration, the higher the salt content that the cheese will have.

The cheese with $L$. plantarum TW14 and L. rhamnosus TW2 obtains water content ranging from $40.19 \pm 3.17$ to $57.33 \pm 0.62 \%$, and it can be classified 


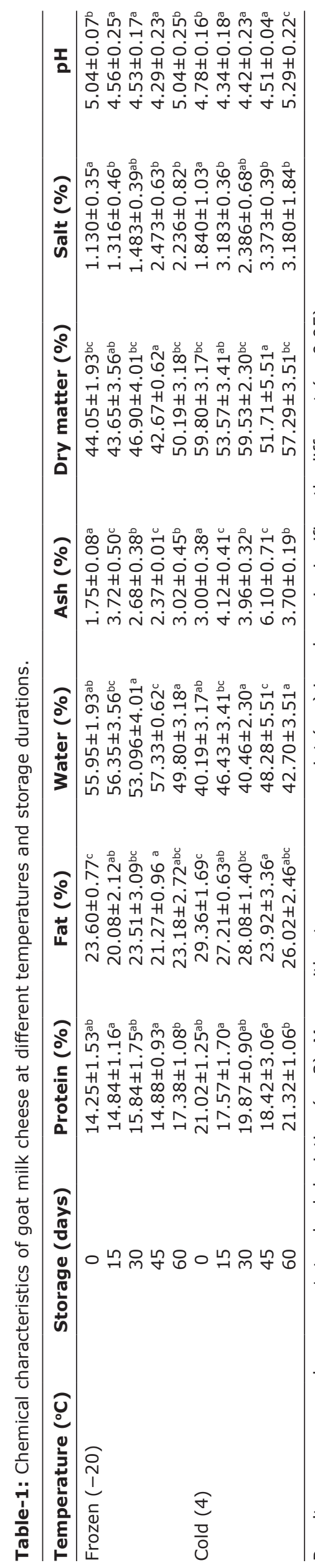

as soft cheese. The cheese's total solids range from $42.67 \pm 0.62$ to $59.80 \pm 3.17 \%$. The lowest total solids are found in the cheese stored at freezer temperature for 45 days. The result of variance analysis shows that cheese storage temperature and storage duration up to 60 days have a significant influence $(p<0.05)$. An increase in the total solids during the cheese ripening is also found by the research conducted by Dervisoglu [12], which is followed by a significant decrease in the cheese water content. The $\mathrm{pH}$ of cheese produced using mixed culture of $L$. plantarum TW14 and L. rhamnosus TW2 was between $4.29 \pm 0.24$ and $5.29 \pm 0.22$ after 30 -day of storage. The probiotic LAB activity during the processing and product storage can be observed by seeing the change in $\mathrm{pH}$ and LAB amount. The result of analysis of variance (ANOVA) indicates that cheese storage temperature and storage duration up to 60 days have a significant influence $(p<0.05)$ on the cheese $\mathrm{pH}$ value. The cheese $\mathrm{pH}$ value is influenced by storage time. The longer the cheese stored at freezer and refrigerator temperatures, the lower the $\mathrm{pH}$ value. However, the $\mathrm{pH}$ value tended to increase after 60 -day of storage.

The protein and total solid contents of cheese samples stored under refrigeration temperature is higher than those of the stored under frozen condition. The increased in total solids of cold-stored cheese are influenced by the components which make up the total solids and the decreased water when the cheese is stored. This result confirms the study by Mushtaq et al. [13]. The increased total solids during the cheese ripening period are due to water evaporation during the cold storage. This confirms the previous study, namely on Kulek cheese. The decreased water content during the cheese cold storage occurs due to the cheese's syneresis process. The decreased water content when the cheese is stored [12], generally because the salt added to the cheese production process will increase the cheese's total solids, and hence, the water content decreases.

During the cheese storage, LAB keeps on growing, develops with the cheese substrates, and produces metabolites in the form of lactic acid which is capable of decreasing the cheese's $\mathrm{pH}$. The low $\mathrm{pH}$ value of the cheese during storage plays a role in helping to create a non-conducive environment for other bacteria to grow and develop, particularly the pathogen and deteriorating bacteria. At the end of the product storage, there is no increase in the $\mathrm{pH}$ value. This indicates that the LAB cultures used are still actively performing metabolism activities, resulting in active production of lactic acid which, in turn, accumulates the lactic acid and the cheese's $\mathrm{pH}$ keeps decreasing. In general, increment of $\mathrm{pH}$ is contributed to the activities of mold and yeast in using lactic acid as the source of carbons, and to the proteolysis process which releases a large amount of alkaline components. These results confirm that cheeses stored for 60 days have an increased $\mathrm{pH}$ value. 


\section{Cheese lipolysis}

The FFA value shows an increased lipolysis activity, and thus, the concentration of FFA content also increases. The acid number is tightly related to FFA contents. ADV is an estimated number of FFA existing in fat sample calculated as the hydrolysis lipolysis index in milk products.

The storage temperature influences the amount of the cheese FFA and ADV values, where the cheese stored in the refrigerator has higher FFA and ADV values those stored at frozen temperature. In the frozen storage, the FFA and ADV values decrease in the 60-day storage duration, and in the cheese stored in refrigerator, the FFA and ADV values increase after 45-day storage. This experiment showed that the FFA content of the cheese after 30-day of storage was $3.09 \pm 1.37$ and increased to $11.95 \pm 0.33$ after 60 -day of storage at refrigerator temperature. During frozen storage, the FFA content did not increase; it even decreased when the cheese is stored until the $30^{\text {th }}$ day. The result of ANOVA shows that the cheese storage, duration, and their interaction have a significant influence $(\mathrm{p}<0.05)$ on the cheese FFA value. During the frozen storage $\left(-20^{\circ} \mathrm{C}\right)$, the FFA value decreases significantly, and the 60-day storage has the lowest FFA value, i.e., 2.05.

This differs from the FFA value of cheese stored in the refrigerator $\left(4^{\circ} \mathrm{C}\right)$, where the cheese FFA value increases after 30-day storage, i.e., in the $45^{\text {th }}$ and $60^{\text {th }}$ days. For 60 days, the highest FFA value is 11.95 , indicating that lipolysis occurs in the cheese stored at cold/refrigerator temperature as shown by the magnitude of FFA value at the end of the cheese storage, even though this FFA value in 60-day storage is not different from the cheese before it is stored, i.e., 7.21. The FFA value of cheese stored at cold temperature in $0-, 15-, 30-, 45-$, and 60-day storages is 7.21, 10.28, $3.09,11.13$, and $0.42 \pm 0.02$, respectively. In the 30 -day storage, the cheese FFA value decreases, which is enabled by the decreased activity of lipoprotein lipase as compared to the 45- and 60-day storages.

The research result shows that the acid number of the cheese after being stored for 60 days ranges between $0.11 \pm 0.05$ and $11.95 \pm 0.33$. During the storage, the FFA content does not increase; it even decreases when the cheese is stored until the $30^{\text {th }}$ day. The result of variance analysis shows that cheese storage temperature, storage duration up to 60 days, and interaction have a significant influence $(\mathrm{p}<0.05)$ on the cheese's acid number. The ADV value in the cheese stored at frozen storage decreases at the end of the storage, i.e., at 0.07 , yet in the cold-stored cheese, the cheese's ADV value increases in the 60-day storage, i.e., at 0.42 . The ADV result has the same tendency as the cheese FFA value. In frozen storage, the ADV is very low, indicating that very small lipolysis occurs as compared to the cold temperature storage.

At the end of the frozen storage, the FFA value does not increase. This indicates that there is no damage to the fat in the cheese stored for 60 days. During the freezing time, no fat globule in the cheese is damaged due to the formation of ice crystal when the cheese is kept in frozen storage. The milk fat naturally exists in the fat globule which is reinforced by the phospholipid and membrane-rich of proteins undamaged by the formation of crystal during the freezing. During the freezing, the FFA value does not increase. The cheese's FFA value in cold storage is higher than that in frozen storage, and at the end of cold storage, the highest FFA value is 7.21. The FFA value shows that lipolysis occurs in the cold-stored cheese. The lipolysis in the cheese during the storage is influenced by some factors such as lipase enzyme, factors existing within the milk, rennet, and the microbes developing during the cheese ripening process [14].

Some researchers report that the lipolysis process in milk and its products can occur in different ways, namely: (1) induced lipolysis, (2) spontaneous lipolysis, and (3) lipolysis caused by microbes. The induced lipolysis is influenced by several factors including the stirring, separation, mixing, presence of air, homogenization, and changes in temperature such as freezing, thawing, storage, and processing [15]. Spontaneous lipolysis occurs with two main factors, namely processing and the factors from the livestock themselves. Lipolysis by microbe is caused by several bacteria contaminating the product. The microbe produces lipase which generates rancid flavor. The decreased total fat measured, particularly triacylglycerol, constitutes the cause of lipolysis by lipoprotein lipase. The full fat cheeses stored under cold temperature have higher FFA value than low-fat cheese. This is due to the lipolytic enzyme activity in lipoprotein deriving from milk indigenous enzyme or microbial enzyme which may damage the milk fat globule membrane when the milk is separated from the fat, during the processing and storage [9].

The cheese's ADV value has the same tendency as the FFA value, wherein cold storage, the ADV increases at the end of storage, i.e. at 0.42 . This result is far below the ADV in feta cheese which is ripened for 60 days at $3-4^{\circ} \mathrm{C}$, i.e. at 1.04 [15]. The lipolysis is indicated by the increase in the cheese sample's ADV value (Table-2). The table indicates that the low ADV value in both cheese storages for 60 days shows the low lipolysis process. The ADV value produced in this research is lower than that what is found by Oliveira [16] and confirms the result obtained by Nouira et al. [9]. In general, the low ADV value shows the less lipolysis occurring in the cheese which is in line with the FFA results.

The main factors influencing cheese lipolysis are fatty acid composition, lipolytic enzyme, lipolytic microbe, water, temperature, storage duration, oxygen, and surface area. The lipolysis in goat cheese can be estimated from ADV and the cheese FFA concentration. 


\section{Cheese's microbiology}

The research result showed that the amount of the cheese's LAB after being stored for 60 days ranges between $8.27 \pm 0.30 \log \mathrm{CFU} / \mathrm{g}$ and $9.143 \pm 0.50 \mathrm{log}$ CFU/g (Table-3). During the storage, the amount of total average $\mathrm{LAB}$ is $8.81 \log \mathrm{CFU} / \mathrm{g}$, meaning that no increase is found. It even decreases when the cheese is stored until the $30^{\text {th }}$ day. Cheese storage temperature, the storage duration up to 60 days, and the interaction have an insignificant influence $(p>0.05)$ on the cheese's LAB.

The frozen storage in goat cheese is highly desired to maintain the cheese quality during distribution and marketing. Information on goat cheese's microbiological quality during its storage in freezer and at cold temperature is still limited, particularly to discover the microbiological characteristics as seen from the total bacteria calculated in the cheese stored in freezer and refrigerator where both have the same tendency, yet their storage durations influence the total bacteria $(\mathrm{p}<0.05)$. The total bacteria of goat cheese which is on 0-day frozen storage is lower than on cold temperature storage which indicates that bacteria is more resistant to cold temperature than to frozen temperature before the cheese is stored. At cold temperature, bacteria can still grow even though its progress is slow. In the 60-day storage, the number of

Table-2: FFA and ADV contents of goat milk cheese stored at different temperatures and storage durations.

\begin{tabular}{lccc}
\hline Temperature ( $\left.{ }^{\circ} \mathbf{C}\right)$ & $\begin{array}{c}\text { Storage } \\
\text { (days) }\end{array}$ & FFA (\%) & ADV (\%) \\
\hline Frozen (-20) & 0 & $7.62 \pm 1.42^{\mathrm{a}}$ & $0.27 \pm 0.05^{\mathrm{a}}$ \\
& 15 & $7.66 \pm 0.51^{\mathrm{a}}$ & $0.27 \pm 0.01^{\mathrm{a}}$ \\
& 30 & $4.35 \pm 0.39^{\mathrm{b}}$ & $0.15 \pm 0.01^{\mathrm{b}}$ \\
& 45 & $6.73 \pm 0.60^{\mathrm{a}}$ & $0.23 \pm 0.02^{\mathrm{a}}$ \\
& 60 & $2.05 \pm 0.55^{\mathrm{b}}$ & $0.07 \pm 0.01^{\mathrm{b}}$ \\
Cold (4) & 0 & $7.21 \pm 0.91^{\mathrm{a}}$ & $0.25 \pm 0.03^{\mathrm{a}}$ \\
& 15 & $10.28 \pm 0.75^{\mathrm{a}}$ & $0.36 \pm 0.02^{\mathrm{a}}$ \\
& 30 & $3.09 \pm 1.37^{\mathrm{b}}$ & $0.11 \pm 0.04^{\mathrm{b}}$ \\
& 45 & $11.13 \pm 4.21^{\mathrm{a}}$ & $0.39 \pm 0.14^{\mathrm{a}}$ \\
& 60 & $11.95 \pm 0.33^{\mathrm{a}}$ & $0.42 \pm 0.02^{\mathrm{a}}$ \\
\hline
\end{tabular}

Results are expressed as mean \pm standard deviation $(n=3)$. Mean without common superscript (a-c) in column are significantly different $(p<0.05)$. FFA=Free fatty acid, ADV $=$ Acids degree value bacteria decreases up to $3 \log$ cycle. This indicates that the total bacteria calculated in the cheese after 45-day storage begins to be dominated by LAB, and hence, the number of bacteria decreases significantly. This result is supported by the data on the amount of LAB experiencing an increase after 30 days of cold storage duration, i.e., at $9.143 \log \mathrm{CFU} / \mathrm{g}$. The bacteria existing in the cheese are secondary microflora deriving from milk or another contaminant during the cheese production process. The total LAB of the cheese stored at both freezer and refrigerator temperatures is relatively the same. However, in the 60-day storage duration, the total LAB increases significantly $(\mathrm{p}<0.05)$ at both storage temperatures. The increased LAB in the cheese stored at cold temperature begins since the $30^{\text {th }}$ day of storage, and in the frozen-stored cheese, the total LAB increase begins after the $45^{\text {th }}$ day.

The total yeast in the cheese is $2.393 \pm 0.56$ $5.570 \pm 0.0$ with a total average of $4.532 \pm 1.15 \log$ $\mathrm{CFU} / \mathrm{g}$. The storage temperature has a significant influence $(p<0.05)$ on the cheese's total yeast. The total yeast in frozen storage is lower than that in refrigerator storage, yet it has the same tendency as in the cheese store for 60 days which has the highest total yeast value. The total yeast decreases on the $15^{\text {th }}$ and $30^{\text {th }}$ days of the storage duration, yet it re-increases in the $45^{\text {th }}$ day. In the frozen storage, the fact that ice crystal is formed has caused the bacteria, including the yeast, to take more time to adapt to the new environment, resulting in its decreased number. In the $45^{\text {th }}$ day of the storage, it begins to be able to adapt, and the total yeast increases until the end of the 60-day storage. This phenomenon is a little bit different from the cheese stored at cold temperature. Before its storage, the cheese has the least total yeast, i.e., $4.123 \log \mathrm{CFU} / \mathrm{g}$ and it increases during the 60-day storage. In the cold storage, the yeast can still grow and multiply in the cheese matrix, where the yeast in the cheese constitutes a contaminant which possibly comes from the milk or during processing.

For the 60-day cheese storage at cold temperature, the total bacteria decreases drastically, i.e., 5.06 $\log \mathrm{CFU} / \mathrm{g}$ as compared to the cheese stored at frozen. At cold temperature, the bacteria can still slowly

Table-3: Microbiological characteristics of goat milk cheese stored at different temperatures and storage durations $(\log \mathrm{CFU} / \mathrm{g})$.

\begin{tabular}{lcccc}
\hline Temperature $\left({ }^{\circ} \mathbf{C}\right)$ & Storage (days) & Amount of total bacteria & LAB & Yeast \\
\hline Frozen $(-20)$ & 0 & $8.173 \pm 1.73$ & $9.027 \pm 0.23^{\mathrm{a}}$ & $4.757 \pm 0.13^{\mathrm{b}}$ \\
& 15 & $8.510 \pm 0.11$ & $8.607 \pm 0.09^{\mathrm{a}}$ & $3.027 \pm 0.39^{\mathrm{ab}}$ \\
& 30 & $8.613 \pm 0.70$ & $8.427 \pm 0.30^{\mathrm{abc}}$ & $2.393 \pm 0.56^{\mathrm{a}}$ \\
& 45 & $8.540 \pm 0.36$ & $8.580 \pm 0.29^{\mathrm{abc}}$ & $3.673 \pm 0.50^{\mathrm{b}}$ \\
& 60 & $8.417 \pm 0.25$ & $9.006 \pm 0.35^{\mathrm{bc}}$ & $5.367 \pm 0.19^{\mathrm{c}}$ \\
& 0 & $9.297 \pm 0.66$ & $8.813 \pm 0.08^{\mathrm{a}}$ & $4.123 \pm 0.48^{\mathrm{b}}$ \\
& 15 & $8.733 \pm 0.12$ & $8.617 \pm 0.13^{\mathrm{a}}$ & $5.570 \pm 0.01^{\mathrm{ab}}$ \\
& 30 & $8.777 \pm 0.04$ & $8.847 \pm 0.15^{\mathrm{abc}}$ & $5.553 \pm 0.07^{\mathrm{a}}$ \\
& 45 & $8.467 \pm 0.04$ & $9.143 \pm 0.50^{\mathrm{abc}}$ & $5.430 \pm 0.21^{\mathrm{b}}$ \\
& 60 & $5.060 \pm 0.08$ & $9.093 \pm 0.14^{\mathrm{bc}}$ & $5.457 \pm 0.04^{\mathrm{bc}}$ \\
\hline
\end{tabular}

Results are expressed as mean \pm standard deviation $(n=3)$. Mean without common superscript $(a-c)$ in column is different $(p<0.05)$. $L A B=$ Lactic acid bacteria, CFU=Colony-forming unit 
grow. On the $60^{\text {th }}$ day of storage, the number of bacteria decreases up to $3 \log$ cycles. This indicates that the total bacteria calculated in the cheese after 45-day storage begins to be dominated by LAB, and hence, the number of bacteria decreases significantly. This result is supported by the data on the amount of LAB experiencing an increase after 30 days of cold storage duration, i.e., at $9.14 \log \mathrm{CFU} / \mathrm{g}$. The bacteria existing in the cheese are secondary microflora deriving from milk or another contaminant during the cheese production process.

This shows that, in cold temperature storage, LAB still performs metabolism and can multiply and produces higher viability than in the frozen-stored cheese. In addition, cheese is one of the ideal probiotic bacteria/LAB carriers as compared to other fermentation products because cheese has $\mathrm{pH}$ close to buffer $\mathrm{pH}$. In addition, the $\mathrm{LAB}$ in cheese is protected within the cheese matrix which contains fat, protein, and others. The cheese's water content is relatively lower than other fermentation products such as yogurt. LAB are the ones dominating when the cheese is stored with the average total LAB being $8.81 \log$ CFU/g. Meanwhile, yeast also grows during the cheese storage at a total average of $4.53 \pm 1.15 \mathrm{log} C F U / g$. In this research, the yeast grows more slowly than LAB.

The existence of yeast in cheese product is possible due to the contamination during the cheese production process, that is, in the curdling process, during the cheese salting in salt solution and the tools used. The number of yeast calculated in the coldstored cheese is higher than that in frozen-stored cheese. This result confirms the research conducted by Park [17] which finds that frozen-stored cheese has a fewer number of yeast than before it is stored. The existence of yeast in the cheese is possible due to cross-contamination during processing and handling. The increased number of yeast at the end of storage duration at both temperatures is because the yeast can metabolize the lactic acid produced by the $\mathrm{LAB}$, and thus, the cheese's $\mathrm{pH}$ at the end of storage increases. The yeast growth is possible due to contamination during the curd formation process, during salting and tool contamination. During the storage, the number of yeast increases significantly. This result confirms the research conducted by Kołakowski [18]. During ripening, the microflora population increases until 4-week storage and slowly decreases until 12 weeks. The total LAB increases at $0.5 \log$ cycle, and at the same time, the yeast also increases from $4 \log$ to $6 \mathrm{log} / \mathrm{g}$ after 12 weeks of ripening period [18]. Ong et al. [19] indicate that the number of Lactobacillus acidophilus and Lactobacillus casei is $8 \log \mathrm{CFU} \mathrm{g}^{-1}$ in cheddar cheese for 6-month storage period. Souza et al. [20] tested the stability of L. acidophilus in Brazilian fresh cheese (Minas fresh cheese) for 3 weeks [21]., and proved the stability of $L$. acidophilus and $L$. casei mixture in soft cheese stored for 8 weeks which can maintain its number $\left(9 \log \mathrm{CFU} \mathrm{g} \mathrm{g}^{-1}\right)$. The viability of
Lactobacillus paracasei A13 increases in the cheese stored at $5^{\circ} \mathrm{C}[22]$.

\section{Cheese change during the storage in electrophoresis}

Proteolysis plays a role during the cheese ripening process by producing aroma through the formation of peptide and amino acid and the cheese texture change from protein matrix breakdown [23].

The cheese stored at frozen temperature has a molecular weight between 10 and $260 \mathrm{kDa}$, where the casein group of the cheese falls within the range of $\mathrm{BM} 17-28 \mathrm{kDa}$. As long as the cheese is stored at frozen temperature for 60 days, the band belonging to the BM 17-28 range remains. The group belongs to $\alpha_{\mathrm{s} 1}$-casein with $\mathrm{BM} 23 \mathrm{kDa}, \alpha_{\mathrm{s} 2}$-casein with $\mathrm{BM}$ $25 \mathrm{kDa}, \beta$-casein with BM $24 \mathrm{kDa}$, and $\kappa$-casein with BM $19 \mathrm{kDa}$ [24]. The profile seems to be overlapping as no perfect separation from the band has occurred yet, particularly within the BM 17-28 $\mathrm{kDa}$ range. All bands were still detected in all samples until the end of 60-day storage. This shows that the breakdown by plasmin occurs only partially, and hence, no protein hydrolysis occurs in the samples. This partial hydrolysis in the cheese samples is possible due to the low $\mathrm{pH}$ as in the case of salted cheese [21].

The proteolysis profile (Figure-3) in frozen-stored cheese for 60 days shows intact bands until the end of storage. Casein protein $\left(\alpha_{\mathrm{s} 1}\right.$-casein, $\alpha_{\mathrm{s} 1}$-casein, and $\beta$-casein) of frozen-stored cheese does not experience any proteolysis, which is possible because the freezing gives minor influence on the cheese composition, including the cheese casein; the freezing does not damage the cheese protein structure, and hence, the proteolysis process occurs only partially. In goat cheese, the proteolysis process begins with a change in the $\alpha_{\mathrm{s}}$-casein rather than in $\beta$-casein [25] because, in frozen-stored goat cheese, no proteolysis occurs until the $60^{\text {th }}$ day of storage.

The partial proteolysis occurring in the casein in electrophoresis pattern shows protein breakdown with

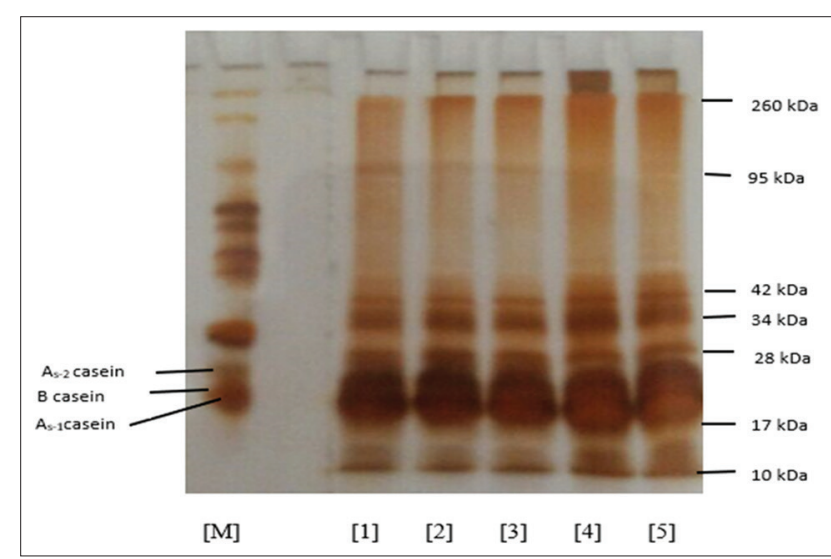

Figure-3: Proteolysis profile with sodium dodecyl sulfatepolyacrylamide gel electrophoresis of the cheese stored at frozen temperature for 60 days. Note: $[\mathrm{M}]=$ Marker; [1] = 0-day cheese storage; [2] = 15-day cheese storage; [3] = 30-day cheese storage; [4] = 45-day cheese storage; and $[5]=60$-day cheese storage. 
lower molecular weight migrating faster and possibly related to the further degradation of the cheese peptide. The qualitative evaluation of goat cheese stored in frozen/freezer temperature with electrophoresis profile indicates that the cheese sample has homogeneity in the proteolytic profile, and hence, there was no band difference between storages. The casein breakdowns detected until the $60^{\text {th }}$ day of storage are $\alpha_{\mathrm{s} 1}$-casein, $\alpha_{\text {s }}$-casein, $\beta$-casein, and $\kappa$-casein. Cheese is a source of $\alpha$-casein and $\beta$-casein, which is broken down from peptides with high, medium, and low molecular weights such as the case of amino acid when it is hydrolized [16]. In goat cheese, $\beta$-casein is the main casein group, and this fraction is important to form and solidify the cheese [26]. $\alpha_{\mathrm{s} 2}$-casein exists in mammal's milk in high amount in goat milk [27]. During the cheese production and storage processes, the peptides will be released by the proteolytic enzyme to be certain casein fraction. The breakdown of protein into $\kappa$-casein becomes important since $\kappa$-casein exists in the outer part of casein micelle which plays some role in the cheese stability and texture [28].

In standard condition, the electrophoresis mobility, $\beta$-casein is the main component of the casein breakdown product in goat milk, where the estimated percentage of the breakdown of the total caseins, i.e., for $\alpha$-casein and $\beta$-casein in goat, is 5.6 and 38 , respectively [29]. Goat milk has higher $\alpha_{\mathrm{s} 2}$-casein and $\kappa$-casein concentrations than cow milk.

\section{Conclusion}

The physicochemical characteristics of coldstored cheese are better than the cheese stored at frozen temperature. However, frozen-stored cheese produces lower FFA and ADV than cold-stored cheese and lipolysis occurs only partially. Frozen-stored cheese can maintain the number of LAB and lower total yeast as the contaminant factor in the cheese production process. The proteolysis of frozen-stored cheese is detected from the presence of $\alpha_{\mathrm{s} 1}$-casein, $\alpha_{\mathrm{s} 2}$-casein, $\beta$-casein, and $\kappa$-casein in the casein breakdown for 60-day storage.

\section{Authors' Contributions}

TS designed the research. JS and KW collected and prepared the milk sample. The cheese was made by TS, and then, chemical analyses were performed by all of the authors. JS and KW analyzed and interpreted the result. TS drafted the manuscript. All authors read and approved the final manuscript.

\section{Acknowledgments}

This study received financial support from the Directorate General of Higher Education of Indonesia through the National Strategic Research Scheme (Grant No. 2411/UN/23.10).

\section{Competing Interests}

The authors declare that they have no competing interests.

\section{Publisher's Note}

Veterinary World remains neutral with regard to jurisdictional claims in published institutional affiliation.

\section{References}

1. Setyawardani, T., Rahayu, W., Maheswari, R. and Palupi, N. (2011) Identification and characterization of probiotic lactic acid bacteria isolated from indigenous goat milk. Anim. Prod., 13(1): 57-63.

2. Setyawardani, T., Rahayu, W.P., Maheswari, R.R.A. and Palupi, N.S. (2014) Antimicrobial activity and adhesion ability of indigenous lactic acid bacteria isolated from goat milk. Int. Food Res. J., 21(3): 959-964.

3. Setyawardani, T., Rahayu, W.P. and Palupi, N.S. (2016) Physicochemical and stability of goat cheese with mono and mixed culture of Lactobacillus plantarum and Lactobacillus rhamnosus. Anim. Prod., 1(2): 36-42.

4. Madureira, A.R., Soares, J.C., Pintado, M.E., Gomes, A.M.P., Freitas, A.C. and Malcata, F.X. (2015) Effect of the incorporation of salted additives on probiotic whey cheeses. Food Biosci., 10(1): 8-17.

5. Bezerra, T.K.A., Arcanjo, N.M.D., Araújo, A.R.R., Queiroz, A.L.M., Oliveira, M.E.G., Gomes, A.M.P. and Madruga, M.S. (2017) Volatile profile in goat coalho cheese supplemented with probiotic lactic acid bacteria. LWT Food Sci. Technol., 76(Part B): 209-215.

6. AOAC. (2006) Official Method of Analysis. 15 $5^{\text {th }}$ ed. Association of Official Analytical Chemists Inc., Virginia USA.

7. James, C. (1995) Analytical Chemistry of Food. $1^{\text {st }}$ ed. Blackle Academic and Profesional, The United Kingdom.

8. Burns, P., Patrignani, F., Serrazanetti, D., Vinderola, G., Reinheimer, J., Lanciotti, R. and Guerzoni, M. (2008) Probiotic crescenza cheese containing Lactobacillus casei and Lactobacillus acidophilus manufactured with high-pressure homogenized milk. J. Dairy Sci., 91(2): 500-512.

9. Nouira, W., Park, Y.W., Guler, Z. and Terrill, T. (2011) Comparison of free fatty acid composition between low-fat and full-fat goat milk cheeses stored for 3 months under refrigeration. J. Anim. Sci., 1(02): 17.

10. Park, Y., Lee, J. and Lee, S. (2006) Effects of frozen and refrigerated storage on organic acid profiles of goat milk plain soft and Monterey jack cheeses. J. Dairy Sci., 89(3): 862-871.

11. Laemmli, U.K. (1970) Cleavage of structural proteins during the assembly of the head of bacteriophage T4. Nature, 227(5259): 680-685.

12. Dervisoglu, M. and Aydemir, O. (2007) Physicochemical and microbiological characteristics of kulek cheese made from raw and heat-treated milk. World J. Microbiol Biotechnol., 23(4): 451-460.

13. Mushtaq, M., Gani, A., Shetty, P.H., Masoodi, F.A. and Ahmad, M. (2015) Himalayan cheese (Kalari/kradi): Effect of different storage temperatures on its physicochemical, microbiological and antioxidant properties. LWT Food Sci. Technol., 63(2): 837-845.

14. Vélez, M., Perotti, M., Wolf, I., Hynes, E. and Zalazar, C. (2010) Influence of milk pretreatment on production of free fatty acids and volatile compounds in hard cheeses: Heat treatment and mechanical agitation. J. Dairy Sci., 93(10): 4545-4554.

15. Evers, J.M. (2004) The milk fat globule membrane compositional and structural changes post secretion by the mammary secretory cell. Int Dairy J., 14(8): 661-674.

16. Oliveira, M.E.G., Garcia, E.F., Queiroga, R.D.C. and Souza, E.L.D. (2012) Technological, physicochemical and sensory characteristics of Brazilian semi-hard goat cheese (coalho) with added probiotic lactic acid bacteria. Sci. Agric., 69(6): 370-379. 
17. Park, Y., Kalantari, A. and Frank, J. (2004) Changes in the microflora of commercial soft goat milk cheese during refrigerated and frozen storage. Small Rumin. Res., 53(1): 61-66.

18. Kołakowski, P., Podolak, R. and Kowalska, M. (2012) Microbial profile of gouda cheese during ripening in two independent chambers-a short report. Pol. J. Food Nutr. Sci., 62(3): 179-184.

19. Ong, L., Henriksson, A. and Shah, N. (2006) Development of probiotic cheddar cheese containing Lactobacillus acidophilus, Lb. casei, Lb. paracasei and Bifidobacterium Spp. and the influence of these bacteria on proteolytic patterns and production of organic acid. Int. Dairy J., 16(5): 446-456.

20. Souza, C.H.B. and Saad, S.M.I. (2009) Viability of Lactobacillus acidophilus La-5 added solely or in co-culture with a yoghurt starter culture and implications on physicochemical and related properties of Minas fresh cheese during storage. LWT Food Sci. Technol., 42(2): 633-640.

21. Rahayu, W., Kusnandar, F. and Prayitno, W. (2011) Stability of Lactic Acid Bacteria During Processing and Storage of Goat Milk Soft Cheese. In $4^{\text {th }}$ International Seminar of Indonesia Society for Microbiology and IUMS-ISM Out Reach Program of Food Safety Denpasar Indonesia: Microbiology Society, Indonesia.

22. Vinderola, G., Prosello, W., Molinari, F., Ghiberto, D. and
Reinheimer, J. (2009) Growth of Lactobacillus paracasei A13 in Argentinian probiotic cheese and its impact on the characteristics of the product. Int. J. Food Microbiol., 135(2): 171-174.

23. Sousa, M., Ardö, Y. and McSweeney, P. (2001) Advances in the study of proteolysis during cheese ripening. Int. Dairy $J ., 11(4): 327-345$.

24. Wang, J., Su, Y., Jia, F. and Jin, H. (2013) Characterization of casein hydrolysates derived from enzymatic hydrolysis. Chem. Cent. J., 7(1): 62.

25. Hayaloglu, A., Yasar, K., Tolu, C. and Sahingil, D. (2013) Characterizing volatile compounds and proteolysis in gokceada artisanal goat cheese. Small Rumin. Res., 113(1): 187-194.

26. Steele, J., Broadbent, J. and Kok, J. (2013) Perspectives on the contribution of lactic acid bacteria to cheese flavor development. Curr. Opin. Biotechnol., 24(2): 135-141.

27. Selvaggi, M., Laudadio, V., Dario, C. and Tufarelli, V. (2014) Major proteins in goat milk: An updated overview on genetic variability. Mol. Biol. Rep., 41(2): 1035-1048.

28. Albenzio, M. and Santillo, A. (2011) Biochemical characteristics of ewe and goat milk: Effect on the quality of dairy products. Small Rumin. Res., 101(1): 33-40.

29. Remeuf, F. and Lenoir, J. (1986) Relationship between the physicochemical characteristics of goat's milk and its rennetability. Bull. Int. Dairy Federation, 202: 68-72. 